\title{
Seuranta- ja vertailutietojen hyödyntäminen kasvintuotantotilan tuotannon ja talouden kehittämisessä
}

\author{
Heikki Isosaari, Pertti Savela ja Sari Peltonen \\ ProAgria Maaseutukeskusten liitto,Urheilutie 6,01301VANTAA, etunimi.sukunimi@proagria.fi
}

\section{Tiivistelmä}

Tässä tutkimuksessa analysoidaan kevätvehnän viljelyn tuotantopanosten käytön kannattavuutta sekä sadon määrään ja tuotannon kannattavuuteen vaikuttavia tekijöitä Lohkotietopankin käytännön viljelytietojen perusteella vuodelta 2004.

Kasvintuotannon tuloksen seuranta ja arviointi ovat osa maatilan johtamis- ja laatujärjestelmää. Viljelyn tulosten arviointi on tarpeellista, kun suunnitellaan tulevaa, asetetaan tavoitteita ja erityisesti arvioidaan menetelmiä, miten asetettuihin tavoitteisiin päästään. Tulosten arviointi ja vertailu havainnollistavat tilan kehityskohteet sekä auttavat tarkastelemaan parhaisiin tuloksiin johtaneita käytäntöjä. Kun omia tuloksia verrataan muihin tiloihin ja etenkin parhaisiin tiloihin, saadaan tuotannon kehittämisen arvokasta lisätietoa. Kasvintuotannon tulosten seurantaan, arviointiin ja vertailuun on kehitetty ProAgrian tietokantoihin perustuvia työvälineitä: Lohkotietopankki, joka pohjautuu lohkomuistiinpanojen tarkkaan hyödyntämiseen sekä Taloustietopankki, joka kokoaa koko tilan kannattavuutta kuvaavia tunnuslukuja.

Kevätvehnän sato Lohkotietopankkiaineistossa vuodelta 2004 oli $3718 \mathrm{~kg} / \mathrm{ha}$, joka on noin 250 $\mathrm{kg} /$ ha enemmän kuin koko maan keskiarvo. Tutkimusaineisto koostui 1598 lohkosta. Näiden lohkojen yhteenlaskettu ala oli 7109 hehtaaria. Tiedot olivat peräisin 207 tilalta.

Määrällisesti suuri kevätvehnän hehtaarisato tuotti vuonna 2004 paremman taloudellisen tuloksen kuin pieni hehtaarisato. Satotuotot ja konekustannukset vaikuttivat eniten saavutettuun taloudelliseen tulokseen. Tautitorjunta lisäsi satoa tilastollisesti merkittävästi (460 kg/ha). Tautitorjunta ei kuitenkaan tuonut merkittävää taloudellista lisäarvoa.

Useiden muuttujien välisiä yhteyksiä tarkasteltaessa aineistosta estimoitiin nk. yleistetty CobbDouglas -tuotantofunktio ja voittofunktio. Estimoidun tuotantofunktion perusteella suurin vaikutus satoon oli pH-tason nostamisella ja eniten satoa alentava tekijä oli puolestaan siementiheyden nostaminen. Voittofunktion perusteella tukituottojen nousulla on suurempi positiivinen vaikutus kate $C$ :hen kuin satotuottojen nousulla. Suurin negatiivinen vaikutus katteeseen kustannuspuolella oli konekustannuksilla.

Kasvintuotantotilan menestyminen ja kilpailukyvyn parantaminen edellyttää tiloilta tarkkaa tuotannon ja talouden seurantaa sekä vertailutietojen hyödyntämistä. Tilakohtaiset tulosten analysoinnit ovat keskeisiä tuotannon kehittämiseksi, tulosten parantamiseksi ja riskien pienentämiseksi. Lohkotietopankin tietoaineisto tarjoaa mahdollisuuden tilakohtaisten tulosten analysointiin vertailutietojen valossa. Lisäksi tutkimuksellisten tarkastelujen avulla parannetaan Lohkotietopankin tietojen hyödyntämismahdollisuuksia ja saadaan käytäntöä hyödyttäviä tietoja viljelijöille päätöksenteon tueksi.

\author{
Asiasanat \\ kevätvehnä, tuotannon kannattavuus, ekonometria, Lohkotietopankki
}




\title{
Johdanto
}

Kasvintuotannon tulosten seurantaan, arviointiin ja vertailuun on kehitetty ProAgrian tietokantoihin perustuvia työvälineitä. Lohkotietopankki pohjautuu lohkomuistiinpanojen tarkkaan hyödyntämiseen. ProAgrian Lohkotietopankkiin on kerätty kasvitilojen tietoja eli lohkokohtaista viljelytietoa, tuotantopanosten käyttötietoja, sadon määrä- ja laatutietoja sekä taloudellisia laskelmia vuodesta 2000 lähtien. Lohkotietopankissa on tällä hetkellä aineistoa yhteensä n. 183000 hehtaarin alalta. Tietoja lähettäviä tiloja mukana järjestelmässä on noin 1 400. Näistä 550 tilaa kuuluu ProAgrian viljelyn kehittämisryhmiin. Näissä ns. ProViljelys -ryhmissä tilan viljely suunnitellaan yhteistyössä neuvojan kanssa pitkäjänteisesti. Keskeinen osa tulospalvelua on Lohkotietopankista saatavat vertailutiedot, joita analysoidaan sekä neuvojan suunnittelukäynneillä että ryhmäneuvontatilaisuuksissa.

ProViljelys-palvelulla tarkennetaan tuotantopanosten käyttöä ja toimenpiteiden oikeaa ajoitusta kasvukauden aikaisin tilakäynnein tuotannon kannattavuus ja ympäristö huomioiden. Suunnittelun ja toimenpiteiden pohjalle tarvitaan riittävästi tilakohtaisesti mitattua tietoa siitä, missä olosuhteissa ja millä toimenpiteillä viljelyssä onnistutaan. Satokauden päätyttyä selvitetään kasvintuotannon viljelytekninen onnistuminen ja taloudellinen tulos sekä määritetään kehittämiskohteet ja tavoitteet seuraavalle vuodelle.

ProViljelys-palvelua toteutetaan eri puolilla Suomea erityisesti viljan-, nurmirehujen- sekä luomutuotannossa. Suurimman hyödyn palvelusta on saanut, kun se on toteutettu perustamalla viljelyn kehittämisryhmiä. Tällöin viljelijät saavat neuvojan lisäksi vertaistukea ryhmältään.

Tiloilla tarkennetaan viljelysuunnitelman toteutus keväällä mm. viljelykiertoa suunnittelemalla sekä kasvivalikoimaa ja tuotantopanosten käyttöä määrittämällä. Kasvukaudella tehtävät tilakäynnit kohdistuvat maan kasvukunnon arviointiin, erilaisten kasvinsuojelutoimenpiteiden ja lisälannoituksen tarpeen arviointiin ja ajoituksen määrittämiseen. Tilakäynnit voidaan toteuttaa vaihtoehtoisesti myös yhteistapaamisina, ns. pellonpiennartilaisuuksina.

Kehittämisryhmät ovat aktiivisesti mukana hyödyntämässä tutkimuksen uusinta tietoa tai suoraan osallisena tutkimushankkeissa. Tästä ovat esimerkkinä mm. mallasohran tuotantovarmuuteen liittyvä tutkimushanke ja nurmen korjuuaikapalvelun kehittämistä tekstiviestihälytyspalvelun avulla testaava hanke. Lisäksi on järjestetty koulutustilaisuuksia tai tutkijatapaamisia.

Kasvukauden päätyttyä tiloille päivitetään viljelyn lohkomuistiinpanot sekä tehdään talouslaskelma (tuotantokustannuslaskelma) kasvintuotannon kannattavuudesta. Tiedot lähetetään ProAgria Maaseutukeskusten Liiton kehittämään valtakunnalliseen Lohkotietopankkiin edelleen analysoitavaksi. Yhdistämällä tietopankin tiedot eri tiloilta saadaan tilan toiminnan tarkasteluun ja kehittämistavoitteisiin aluekohtaisia ja valtakunnallisia vertailu- ja kehittämistietoja. Lohkotietopankin tietoja voidaan tarkastella internetportaalin välityksellä.

Tässä tutkimuksessa analysoidaan kevätvehnän viljelyn tuotantopanosten käytön kannattavuutta sekä sadon määrään ja tuotannon kannattavuuteen vaikuttavia tekijöitä Lohkotietopankin käytännön viljelytietojen perusteella vuodelta 2004.

\begin{abstract}
Aineisto
Tutkimuskasviksi valittiin kevätvehnä ja tutkimusaineistoksi vuoden 2004 tiedot Lohkotietopankista. Aineistosta tarkasteltiin kevätvehnälohkojen viljavuustietoja ( $\mathrm{pH})$, lannoitustietoja ( $\mathrm{N} \mathrm{kg} / \mathrm{ha}, \mathrm{P} \mathrm{kg} / \mathrm{ha})$, kasvinsuojelutietoja (rikkakasvitorjunta, tautitorjunta, käsittely \% lohkoista), satotuottoja, tukia, muuttuvia kustannuksia, työkustannuksia, kone- ja rakennuskustannuksia sekä yleiskustannuksia (Taulukko 1). Aineistoa käsiteltiin SPSS 13.0 for Windows -ohjelmassa. Bruttoaineisto koostui 1989 lohkosta. Aineistoon tehtiin seuraavat rajaukset: tutkittujen muuttujien arvojen piti olla suurempia kuin nolla. Tätä rajausta ei asetettu lannoitemäärille, eikä taloudellisille tunnusluvuille. Aineiston rajausten jälkeen saatiin tulokseksi tutkittava nettoaineisto, joka koostui 1598 lohkosta. Näiden lohkojen yhteenlaskettu ala oli 7109 hehtaaria. Tiedot olivat peräisin 207 tilalta.
\end{abstract}




\section{Tulokset}

Taulukossa 1 on esitelty tärkeimpien muuttujien tunnuslukuja. Kevätvehnäaineistossa lohkojen välillä oli suuri hajonta taloudellisissa tunnusluvuissa. Suurin keskihajonta oli satotuotoissa ja konekustannuksissa. Kevätvehnän keskiarvo sato Lohkotietopankkiaineistossa oli $3718 \mathrm{~kg} / \mathrm{ha}$, joka on noin $250 \mathrm{~kg} / \mathrm{ha}$ enemmän kuin koko maan keskiarvo. Tämä on kuitenkin yleinen piirre neuvonnallisissa tuloksissa. Tilat, jotka lähettävät tietonsa tietopankkeihin, ovat mukana ProAgrian sopimusneuvonnassa. Tästäkin syystä heidän tuloksensa ovat parempia kuin koko maan keskiarvotulokset.

Taulukko 1. Tärkeimmät muuttujat kevätvehnäaineistossa vuonna 2004

\begin{tabular}{lcc}
\hline & Keskiarvo & Keskihajonta \\
\hline Panokset & & \\
Lohkon pinta-ala, ha & 4,5 & 4,6 \\
pH & 6,2 & 0,5 \\
Lannoitetyppi, kg/ha & 118,5 & 21,6 \\
Lannoitefosfori, kg/ha & 11,7 & 6,9 \\
Siemenmäärä, kg/ha & 278,4 & 26,1 \\
Itavyys, \% & 90,4 & 2,1 \\
Siemenen kylvötiheys, kpl/m2 & 646,3 & 59,2 \\
Tjp, g & 38,9 & 2,4 \\
Työmäärä, h/ha & 12,1 & 3,7 \\
Tuotos & & \\
Sato, kg/ha & 3718,6 & 1067,5 \\
Talous & & \\
Satotuotot, e/ha & 418,5 & 126,5 \\
Tukituotot, e/ha & 636,7 & 20,7 \\
Tuotot yhteensä, e/ha & $\mathbf{1 0 5 5 , 2}$ & $\mathbf{1 2 9 , 0}$ \\
Muuttuvat kustannukset, e/ha & 299,0 & 72,2 \\
Kate A, e/ha & $\mathbf{7 4 6 , 6}$ & $\mathbf{1 4 3 , 1}$ \\
Työkustannus, e/ha & 152,4 & 43,4 \\
Konekustannus, e/ha & 219,5 & 79,6 \\
Rakennuskustannus, e/ha & 47,6 & 34,6 \\
Yleiskustannus, e/ha & 53,5 & 24,7 \\
Kate C, e/ha & $\mathbf{2 6 8 , 5}$ & $\mathbf{1 7 8 , 7}$ \\
\hline
\end{tabular}

\section{Sadon ja taloudellisen tuloksen välinen yhteys}

Tutkimusaineistossa kevätvehnän sato $(\mathrm{kg} / \mathrm{ha})$ ja kate $\mathrm{C}(€ / \mathrm{ha})$ korreloivat merkittävästi (Pearsonin korrelaatiokerroin $+0,304$, Kuva 1). Määrällisesti suuri kevätvehnän hehtaarisato tuotti vuonna 2004 paremman taloudellisen tuloksen kuin pieni hehtaarisato. Jos kate C jää negatiiviseksi, merkitsee se, että viljelijän omasta palkkavaatimuksesta ja oman pääoman tuottovaatimuksesta on jouduttu tinkimään. Viljelijä ei myöskään saa korvausta peltoon sitoutuneelle pääomalle. 


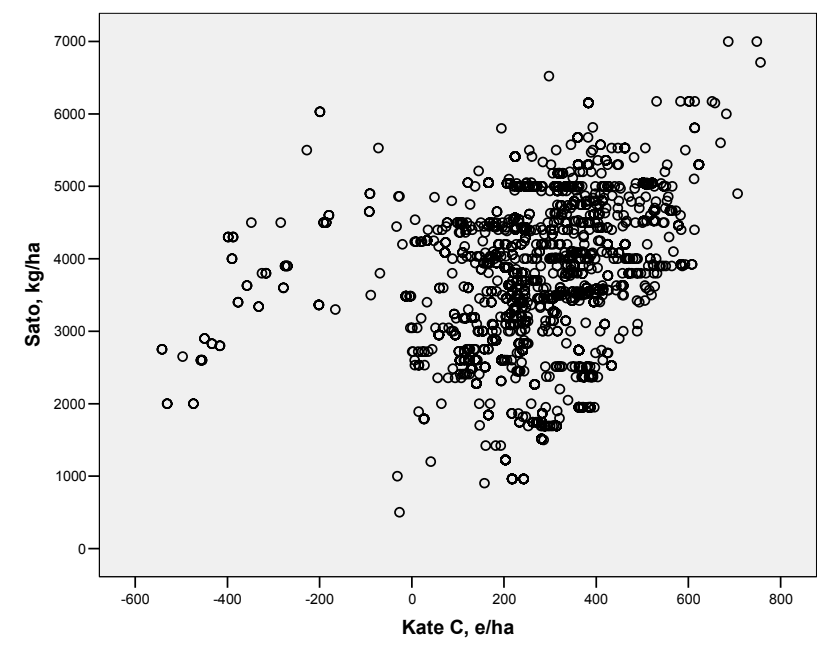

Kuva 1. Hehtaarisadon ja taloudellisen tuloksen välinen yhteys

\section{Sadon ja tautitorjunnan välinen yhteys}

Tutkimusaineistossa rikkakasvitorjunta oli tehty 99,8 prosentilla lohkoista ja tautitorjunta 80,5 prosentilla lohkoista. Kuvassa 2 on esitetty satojakauma hajontoineen siten, että lohkot on jaettu luokkiin sen mukaan, onko tautitorjunta tehty. Mediaanisato, kun tautitorjunta on tehty, on $3808 \mathrm{~kg} / \mathrm{ha}$. Tautitorjunta lisäsi satoa tilastollisesti merkittävästi $(460 \mathrm{~kg} / \mathrm{ha})$. Tautitorjunta ei kuitenkaan tuonut merkittävää taloudellista lisäarvoa. Kate $C$ oli keskimäärin $4 € /$ ha pienempi lohkoilla, joilla tautitorjunta tehtiin. Asia on kuvattu tarkemmin taulukossa 2. Tautitorjunnalla saatu vajaan $500 \mathrm{~kg}: \mathrm{n}$ sadonlisä ei nykyisellä tuotto-kustannusrakenteella vielä osoittautunut taloudellisesti erityisen kannattavaksi.

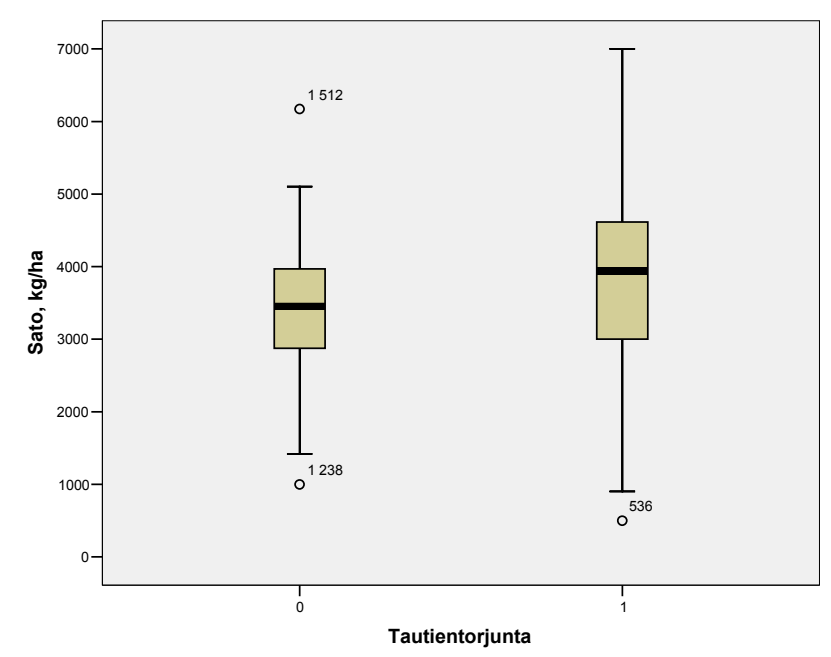

Kuva 2. Satojakauma lohkoilla, joissa tautitorjunta tehtiin (1) ja joissa tautitorjuntaa ei tehty (0). Boxplotkuviossa on esitetty mediaani sekä ylin ja alin kvartiili. Sen lisäksi siinä on esitetty havaintoväli.

Taulukko 2. Tärkeimpien taloustietojen keskiarvot lohkoilla, joissa tautitorjunta tehtiin (1) ja joissa tautitorjuntaa ei tehty $(0)$.

\begin{tabular}{lcc}
\hline & 0 & 1 \\
\hline Tuotot, e/ha & 994,0 & 1070,0 \\
Kate A, e/ha & 729,6 & 750,7 \\
Kate B, e/ha & 579,2 & 591,4 \\
Kate C, e/ha & 270,8 & 267,9
\end{tabular}




\section{Tuotanto-ja voittofunktion estimointi}

Hyödyllisimmän tarkastelukulman aineistoon antaa useiden muuttujien välisten yhteyksien tutkiminen. Yleisesti käytetty tuotantofunktion muoto maataloudessa on nk. yleistetty Cobb-Douglas funktio (esim. Varian 1984, 172). Perusmuodossaan se voidaan esittää seuraavasti:

(1) $\mathrm{Y}=A K^{\mathrm{b}} \mathrm{L}^{\mathrm{c}} \mathrm{T}^{\mathrm{d}}$

missä:

$\mathrm{Y}=$ tuotettu määrä

$\mathrm{K}=$ pääoma

$\mathrm{L}=$ työ

$\mathrm{T}=$ maa

$\mathrm{A}, \mathrm{b}, \mathrm{c}, \mathrm{d}=$ parametrejä

Cobb-Douglas -funktion muuttujista aineistossa pääomaa kuvaavana muuttujana käytettiin konekustannusta, jonka oletetaan olevan positiivisesti korreloitunut konepääoman kanssa. Konekustannus on suurin pääomakustannuserä viljelyssä. Peltoon sitoutunutta pääomaa ei oteta huomioon tässä tarkastelussa. Maata tuotannontekijänä kuvaavat estimoidussa mallissa pH-arvo, lannoitetyppi, lannoitefosfori ja siemenen tiheys. Muuttujista otettiin luonnolliset logaritmit, jotta regressiokertoimet kuvaavat suoraan joustojen arvoja (johto esim. Dillon 1979, 24-25).

Kevätvehnä aineistosta estimoitiin seuraava Cobb-Douglas -tuotantofunktio (suluissa muuttujien Tarvojen itseisarvot ja niiden tilastollinen merkitsevyys):

(2) $\operatorname{lnSATO}=9,6+0,71 \operatorname{lnpH}-0,082 \ln \mathrm{N}+0,032 \ln \mathrm{P}-0,38 \operatorname{lnTIH}+0,12 \operatorname{lnKONEK}-0,11 \operatorname{lnTYÖ}$

$\mathrm{R}^{2}=0,063$

$\left(14,4^{* * *}\right)\left(6,4^{* * *}\right)\left(2,4^{*}\right) \quad\left(1,7^{\circ}\right) \quad\left(4,0^{* * *}\right) \quad\left(4,9^{* * *}\right) \quad\left(3,3^{* *}\right)$

$\mathrm{F}=15,2 * * *$

missä:

$\mathrm{SATO}=$ satomäärä, $\mathrm{kg} / \mathrm{ha}$

$\mathrm{pH}=\mathrm{pH}$-arvo

$\mathrm{N}=$ lannoitetyppi, $\mathrm{kg} / \mathrm{ha}$

$\mathrm{P}=$ lannoitefosfori, $\mathrm{kg} / \mathrm{ha}$

$\mathrm{TIH}=$ siemenen kylvötiheys, $\mathrm{kpl} / \mathrm{m} 2$

KONEK = konekustannus, e/ha

TYÖ = työmäärä, $\mathrm{h} / \mathrm{ha}$

Liitteessä 1 on tarkasteltu estimoidun tuotantofunktion residuaalin normaalisuusoletuksen toteutumista. Merkittävää multikollineaarisuutta ${ }^{1}$ ei riippumattomien muuttujien välillä havaittu. Sitä mittaava VIF-arvo jäi kaikilla muuttujilla alle 1,5. Mallin selitysaste jäi alhaiseksi. Mallin ulkopuolella jäävistä tekijöistä sää lienee ainakin merkittävä satotason selittäjä. Sen sijaan kaikki riippumattomat muuttujat poikkeavat nollasta tilastollisesti merkitsevästi. Muuttujien saamat kertoimet ovat jossain määrin yllättäviä: typpitason ja siementiheyden nostaminen ja työn käytön lisääminen vähentävät satoa. Suurin vaikutus satoon saadaan mallin perusteella $\mathrm{pH}$-tason nostamisella. Eniten satoa alentava tekijä on puolestaan siementiheyden nostaminen.

Yrittäjän saamaa voittoa voidaan kuvata seuraavasti:

(3) $\quad \Pi=\mathrm{TR}-\mathrm{TC}$

missä:

$\Pi=$ voitto

$\mathrm{TR}=$ tuotot

$\mathrm{TC}=$ kustannukset

Kevätvehnäaineistosta estimoitiin seuraava lineaarinen voittofunktio (suluissa muuttujien T-arvojen

1 Multikollineaarisuus tarkoittaa selittävien muuttujien keskinäistä lineaarista riippuvuutta. 
itseisarvot ja niiden tilastollinen merkitsevyys):

(4) KATEC $=-123,6+1,0$ SATOT $+1,1$ TUKIT $-1,4$ SIEK $-1,0 \mathrm{LANK}-2,0 \mathrm{KSK}-0,9 \mathrm{KONEK}-$ $1,5 \mathrm{RAK}-1,1 \mathrm{TYÖK}$ $\begin{array}{lllll}(1,6) & \left(47,0^{* * *}\right) \quad\left(9,0^{* * *}\right) & \left(17,3^{* * *}\right) & \left(12,0^{* * *}\right) & \left(18,6^{* * *}\right)\left(29,2^{* * *}\right)\end{array}$ $\left(20,5^{* * *}\right)\left(19,6^{* * *}\right)$

$\mathrm{R}^{2}=0,71$

$\mathrm{F}=488,2 * * *$

missä (kaikilla muuttujilla yksikkö on e/ha):

$\mathrm{KATEC}=$ kate $\mathrm{C}$

SATOT $=$ satotuotot

TUKIT $=$ tukituotot

SIEK $=$ siemenkustannus

LANK $=$ lannoitekustannus

KSK $=$ kasvinsuojelukustannus

KONEK $=$ konekustannus

RAK = rakennuskustannus

YLEISK = yleiskustannus

TYÖK = työkustannus

Liitteessä 1 on tarkasteltu estimoidun voittofunktion residuaalin normaalisuusoletuksen toteutumista.. Residuaaleissa erottuu ryhmä, jonka mallittaminen vaatii jatkotutkimusta. Tutkimalla havaintoja voitiin huomata, että tällä ryhmällä vakiotermi kuvasi huonosti katelaskelman niitä eriä, joista ei ollut muodostettu omaa riippumatonta muuttujaa. Merkittävää multikollineaarisuutta ei riippumattomien muuttujien välillä havaittu. VIF-arvo jäi kaikilla muuttujilla niinikään alle 1,5.

Muuttujien saamat kertoimet ovat merkiltään odotusten mukaisia: tuottojen lisääntymisellä on voittoa nostava vaikutus ja kustannusten nousulla voittoa alentava vaikutus. Lineaarisessa funktiossa regressiokertoimet ovat joustoja, kun niitä tarkastellaan muuttujien keskiarvokohdassa. Joustojen arvot on esitetty taulukossa 3 . Tukituottojen nousulla on suurempi positiivinen vaikutus kate C:hen kuin satotuottojen nousulla. Tämä on loogista, koska osa kasvavista satotuotoista kuluu kohoaviin kustannuksiin. Suurin negatiivinen vaikutus katteeseen kustannuspuolella on konekustannuksilla, joka on myös merkittävin kustannuserä, noin 30 \% kevätvehnän viljelyn kokonaiskustannuksista.

Taulukko 3. Voittofunktion joustojen arvot, kate C:n muuttuminen riippumattoman muuttujan muuttuessa

\begin{tabular}{lc}
\hline SATOT & 1,61 \\
TUKIT & 2,55 \\
SIEK & $-0,31$ \\
LANK & $-0,39$ \\
KSK & $-0,34$ \\
KONEK & $-0,74$ \\
RAK & $-0,26$ \\
TYÖK & $-0,65$ \\
\hline
\end{tabular}

\section{Johtopäätökset}

Lohkotietopankin tietojen analysointi osoitti, että määrällisesti suuri kevätvehnä hehtaarisato tuotti vuonna 2004 paremman taloudellisen tuloksen kuin pieni hehtaarisato Tautitorjunta lisäsi satoa merkittävästi. Tautitorjunnalla saatu vajaan $500 \mathrm{~kg}: n$ sadonlisä ei nykyisellä tuotto-kustannusrakenteella kuitenkaan ollut taloudellisesti erityisen kannattava. Kevätvehnän satoa ei selittänyt selkeästi mikään yksittäinen viljelytekijä. Estimoidusta Cobb-Douglas-tuotantofunktiosta saatiin tuloksena, että suurin positiivinen vaikutus satoon oli $\mathrm{pH}$-tason nostamisella. Estimoidusta voittofunktiosta saatiin tuloksena, 
että tukituottojen nousulla on suurempi positiivinen vaikutus kate C:hen kuin satotuottojen nousulla. Suurin negatiivinen vaikutus katteeseen on konekustannuksilla, joka on myös merkittävin kustannuserä, noin 30 \% kevätvehnän viljelyn kokonaiskustannuksista.

Lohkotietopankin tulosten analysointi osoitti, että tuotannon eri tekijöiden välillä löytyy merkittäviä yhteyksiä. Tulosten analysoinnin jatkaminen on edellytys sille, että voidaan tehdä jatkopäätelmiä siitä, mitkä ovat tuotannon kriittiset pisteet ja mitä tekijää korjaamalla voidaan tilakohtaista tulosta parantaa. Lisäksi erilaisten raja-arvojen määrittäminen tuotantopanosten käytön kannattavuuksille ovat tärkeitä Lohkotietopankin jatkotutkimuskohteita.

\section{Kirjallisuus}

Dillon, J. 1979. The Analysis of Response in Crop and Livestock Production. Pergamon Press.

Varian, H. 1984. Microeconomic Analysis. W. W. Norton \& Co.

\section{Liite 1:}

\section{Estimoitujen funktioiden residuaalit}

Scatterplot
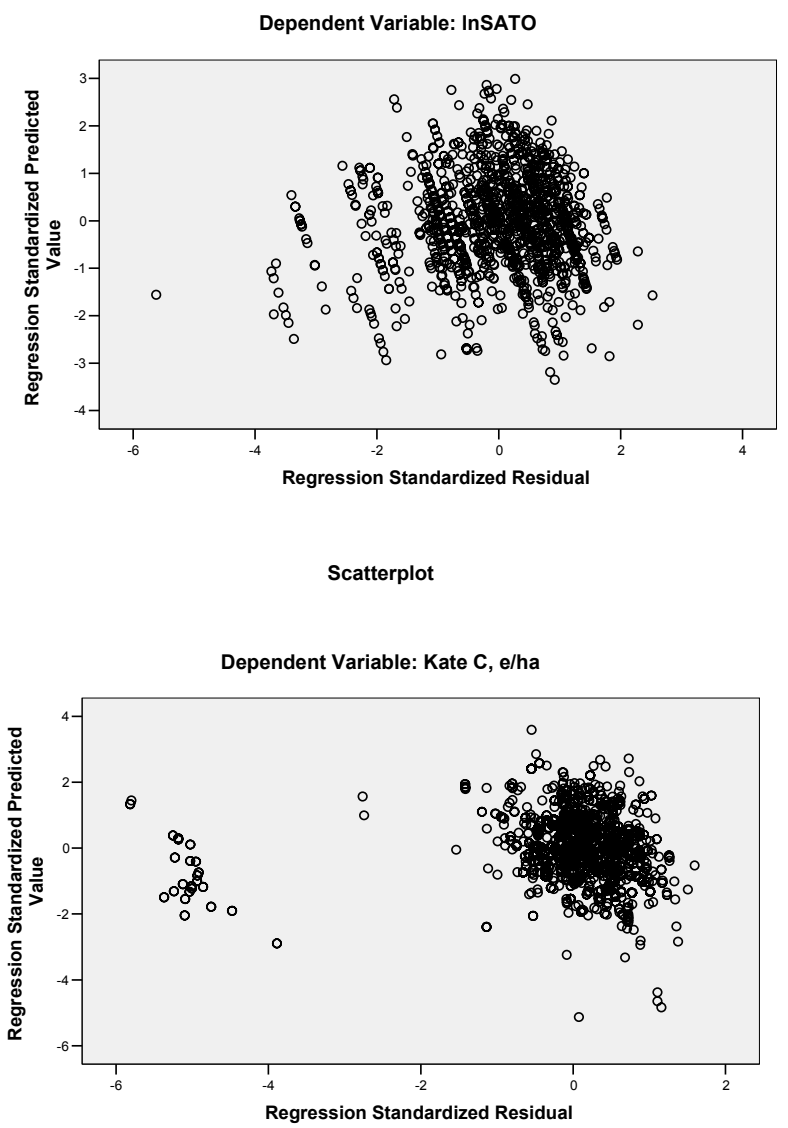